\title{
(6) OPEN ACCESS \\ Congenital intracranial mature teratoma: the role of fetal MRI over ultrasound in the prenatal diagnosis and the perinatal management
}

\author{
Grigorios Gkasdaris, ${ }^{\oplus 1,2}$ Danai Chourmouzi ${ }^{3}$
}

${ }^{1}$ Fourth Surgical Department, Medical School, Aristotle University of Thessaloniki, Thessaloniki, Greece European Interbalkan Medical Center, Thessaloniki, Greece ${ }^{3}$ Department of Diagnostic Radiology, Interbalcan Medical Centre, Thessaloniki, Greece

\section{Correspondence to} Dr Grigorios Gkasdaris, grgkasdaris@gmail.com

Accepted 6 April 2019

\section{DESCRIPTION}

A 30-year-old mother, gravida 2, para 0010, had a normal pregnancy while performing the regular prenatal examinations. From her medical history, there was nothing noteworthy. In the third trimester ultrasonography, at 31 weeks' gestation, a large hypoechoic oval mass was observed in the growing fetal brain parenchyma of the right cerebral hemisphere deviating the midline to the left. Normal intracranial structures were identifiable, and there was no ventricular dilatation. The differential diagnosis included a cerebral cyst versus a fetal cranial neoplasm. Fetal MRI showed a round mass with fine borders and smaller cystic lesions, located at the right temporal lobe, setting the suspicion of teratoma (figure 1).

After discussion with the parents, they chose to proceed with the pregnancy without any intervention. The patient came to spontaneous onset of labour at 36 weeks. The vaginal delivery was successful without any complication. A female infant was delivered, weighing $3260 \mathrm{~g}$ and with head circumference measured $38.2 \mathrm{~cm}$ (>90th percentile). Physical examination revealed a large head with wide fontanels. No other congenital anomaly was observed and neurological examination was normal.

Immediately after the birth, at first postnatal day, a new MRI of the newborn was performed. The mass was hyperintense in T2-weighted MRI scan, with well-defined borders, cystic formations and direct continuation from the encephalic parenchyma (figure 2). In addition, the mass showed contrast enhancement in T1-weighted MRI. At that time, a right temporal craniectomy and total excision of the tumour was considered necessary due to mild ventricular dilatation. The histopathological result from the intraoperative tissue of the mass confirmed the diagnosis of fetal mature teratoma. The infant is under a 5-year follow-up without any indication of recurrence or significant neurological deficits.

Congenital intracranial tumours are rare and account for approximately $0.5 \%-1.5 \%$ of all childhood brain tumours, however teratomas are the most common type representing the majority of brain tumours during pregnancy. ${ }^{1}$ Congenital intracranial teratomas present high frequency of fetal and postnatal death, with overall survival rate being estimated at $7.8 \% .^{2-4}$

They are seen in various sites within the central nervous system: cerebral hemispheres, pineal, hypothalamic area, suprasellar region and third ventricle. ${ }^{4}$ Different forms have been described, as regards to size (huge/small), presentation (causing hydrocephalus or incidental finding) and location (intracranialextracranial). ${ }^{5}$

The average maximum tumour size is $10 \mathrm{~cm}$, with mean age of ultrasound diagnosis at 32 weeks' gestation and no differentiation regarding gender. Most teratomas are detected on routine prenatal ultrasound examination. Major signs are macrocephaly,
Check for updates

(C) BMJ Publishing Group Limited 2019. Re-use permitted under CC BY-NC. No commercial re-use. See rights and permissions. Published by BMJ.

To cite: Gkasdaris $\mathrm{G}$, Chourmouzi D. BMJ Case Rep 2019;12:e229774. doi:10.1136/bcr-2019229774
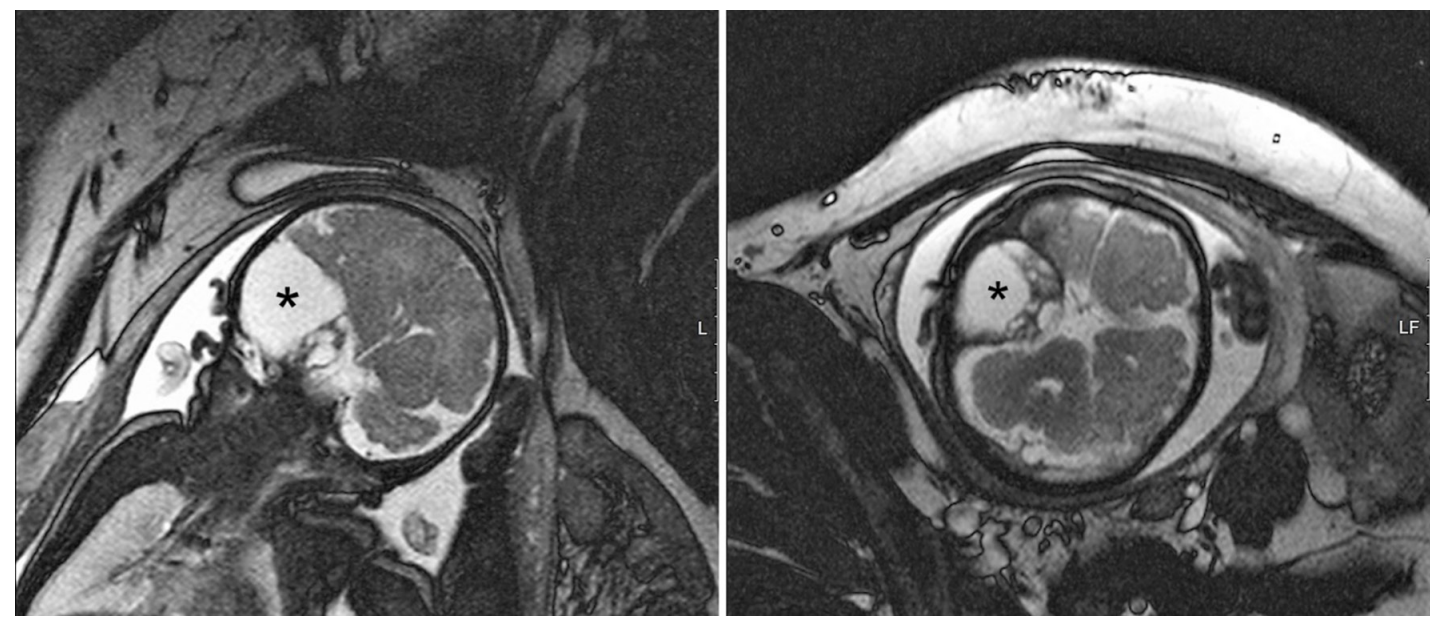

Figure 1 Fetal MRI:T2-weighted coronal MRI (on the left) and T2-weighted axial MRI (on the right) depicting the oval-shaped hyperintense mass (black asterisk) surrounded by cyst-like areas, located in the right temporal lobe of the fetus and slightly deviating the midline to the left. 

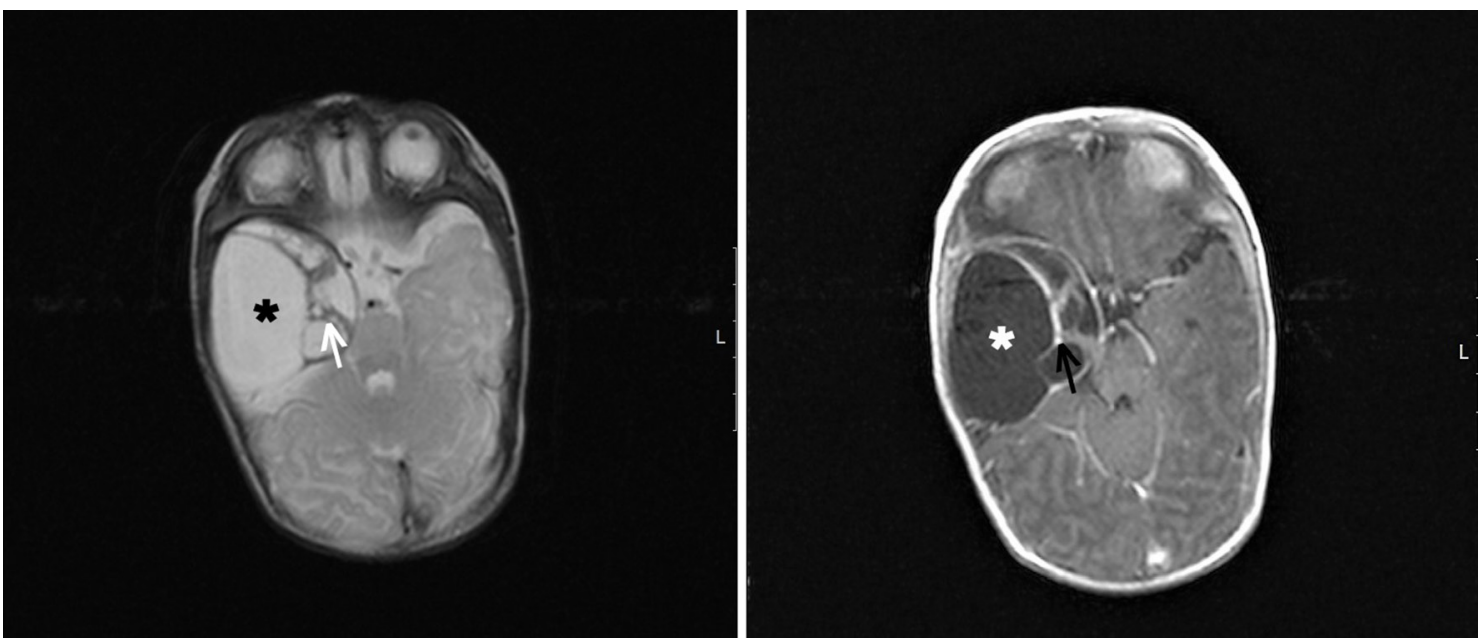

Figure 2 MRI scan after the delivery of the newborn: T2-weighted MRI (on the left) and T1-weighted MRI with contrast (on the right) depicting a heterogenic mass (white and black asterisk) with well-defined borders and cyst-like areas of variable size (white arrow) and contrast enhancement (black arrow).

intracranial mass and hydrocephalus. The sonographic and MRI appearance of the intracranial teratoma is usually that of an irregular heterogenous mass with hyperechogenic and hypoechogenic features, with both solid and cystic areas and/or calcified components, distorting brain anatomy. ${ }^{46}$

The use of MRI, in the perinatal period, is the imaging modality of choice for indicating the morphological features of teratoma, for estimating the feasibility of a possible surgical resection, for allowing the surgeon to better advise the parents on the potential sequelae of surgery and the overall prognosis and thus, for optimising perinatal care. ${ }^{6-8}$

\section{Learning points}

- Congenital intracranial mature teratoma is a rare entity with difficult diagnosis, challenging management and poor prognosis.

- Fetal MRI is the imaging modality of choice for early recognition of teratoma and for optimisation of perinatal management.

Contributors GG performed literature review and manuscript preparation. DC was involved in image description and manuscript review.

Funding The authors have not declared a specific grant for this research from any funding agency in the public, commercial or not-for-profit sectors.
Competing interests None declared.

Patient consent for publication Not required.

Provenance and peer review Not commissioned; externally peer reviewed.

Open access This is an open access article distributed in accordance with the Creative Commons Attribution Non Commercial (CC BY-NC 4.0) license, which permits others to distribute, remix, adapt, build upon this work non-commercially, and license their derivative works on different terms, provided the original work is properly cited and the use is non-commercial. See: http://creativecommons.org/ licenses/by-nc/4.0/

\section{REFERENCES}

1 Geethanath RM, Abdel-Salam F. Congenital intracranial teratoma. BMJ Case Rep 2010:pii: bcr0820092213.

2 Im SH, Wang KC, Kim SK, et al. Congenital intracranial teratoma: prenatal diagnosis and postnatal successful resection. Med Pediatr Oncol 2003;40:57-61.

3 Robles Fradejas M, Gonzalo García I, De Las Casas Quispe AC, et al. Fetal intracranial immature teratoma: presentation of a case and a systematic review of the literature. $J$ Matern Fetal Neonatal Med 2017:30:1139-46.

4 Isaacs H. Fetal intracranial teratoma. A review. Fetal Pediatr Pathol 2014;33:289-92.

5 Juverdeanu S, Ghoshal S, Bullen PJ. Second trimester intracranial fetal teratoma. J Obstet Gynaecol 2012;32:486-8.

6 Milani HJ, Araujo Júnior E, Cavalheiro S, et al. Fetal brain tumors: Prenatal diagnosis by ultrasound and magnetic resonance imaging. World I Radiol 2015:7:17-21.

7 Abdelmuhdi AS, Almazam AE, Dissi NA, et al. Intraoperative, and pathologic features: Airp best cases in radiologic-pathologic correlation. Radiographics 2017:37:1506-11.

8 Cassart M, Bosson N, Garel C, et al. Fetal intracranial tumors: a review of 27 cases. Eur Radiol 2008;18:2060-6.

Copyright 2019 BMJ Publishing Group. All rights reserved. For permission to reuse any of this content visit

https://www.bmj.com/company/products-services/rights-and-licensing/permissions/

BMJ Case Report Fellows may re-use this article for personal use and teaching without any further permission.

Become a Fellow of BMJ Case Reports today and you can:

Submit as many cases as you like

- Enjoy fast sympathetic peer review and rapid publication of accepted articles

- Access all the published articles

- Re-use any of the published material for personal use and teaching without further permission

For information on Institutional Fellowships contact consortiasales@bmjgroup.com

Visit casereports.bmj.com for more articles like this and to become a Fellow 